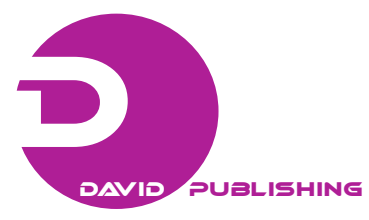

\title{
Economic Consequences of Tahoku Earthquake of March 11, 2011 in Japan
}

\author{
Sergey Baranov ${ }^{1}$ and Tatiana Skufina ${ }^{2}$ \\ 1. Kola Branch of Geophysical Survey of Russian Academy of Sciences, Apatity 18409, Russia \\ 2. Institute of Economics Problems, Kola Science Centre, Russian Academy of Sciences, Apatity 18409, Russia
}

\begin{abstract}
The paper considers the economic consequences of Tahoku earthquake occurred on March 11, 2011 at 5:46:23 (UT) at the distance of $70 \mathrm{~km}$ from the northeast shore of Japanese coast Honshu. This earthquake had a magnitude of 9 and became the strongest in the whole history of the seismological observations in this part of the planet. The generated tsunami killed more than 15,700 people, damaged 332,395 buildings and 2,126 roads. The total economic loss in Japan was estimated at $\$ 309$ billion. The catastrophe in Japan also impacted global economy. To reveal its impact, the authors used regional and global stock indexes, production indexes, stock prices of the main Japanese, European and US companies, and import/export dynamics. The authors demonstrated that the catastrophe substantially affected the markets and on the short run in some indicators it exceeded the effect of the global financial crisis. The authors concluded that it is necessary to treat possible strong earthquakes in different regions of the world as one very important factor that can affect the world economy.
\end{abstract}

Key words: Tahoku earthquake, economics consequences, global economy, stock indexes.

\section{Introduction}

Tahoku earthquake occurred on March 11, 2011 at 5:46:23 (UT) on the distance of $70 \mathrm{~km}$ from the northeast shore of Japanese coast Honshu with the magnitude $^{1} \mathrm{Mw}=9$. This earthquake became the strongest one in the whole history of the seismological observations in this part of the planet. The number of death and missing people is more than 28 thousands.

Three factors define the uniqueness of Tahoku earthquake: First of all, the earthquake is the strongest seismological event in Japan since 1896 and forth by the strength of at least the past three centuries. According to the research of the USGS (United States

Corresponding author: Sergey Baranov, Ph.D., senior researcher, research fields: seismology, seismic wave propagation, seismic hazard and economics. E-mail: bars.vl@gmail.com.

${ }^{1}$ Magnitude of an earthquake is the logarithmic estimation on the scale of seismologic occurrences which are counting by seismological notes. As a rough approximation a shake ability of an earthquake with magnitude of 5 will be 10 times stronger than the earthquake of the magnitude of 4 on the same distance. Increasing of magnitude into 1 quantity of energy the earthquake increases in 32 times.
Geological Survey) [1], closest in power earthquake in the area of Japanese archipelago had magnitude of 8.5 and occurred on June 15, 1896, the number of death toll was 11.5 thousands. The strength of the earthquake of 1896 was five times less than the one of 2011; Secondly, the previous strong earthquakes (Table 1) happened in regions that are not as technologically developed and integrated to the world economy as Japan; Thirdly, first time Tahoku earthquake caused technical catastrophe on the Japanese NPP (nuclear power plant) in Fukushima. People were evacuated from the distance of $30 \mathrm{~km}$ around the place of the catastrophe. The issue of flushing radioactive water into the Pacific Ocean caused the radiation spread on hundreds of kilometers from the Japanese shore [2]. Even a half year after the catastrophe scientists could not come up with the exact idea of further development of the situation and the size of radioactive contamination.

The combination of these three factors make us not only see the problem and mechanism of the global economic system from other perspective but also 
Table 1 Earthquakes with the magnitude greater than 8.5 that have been occurring since 1900 [1].

\begin{tabular}{|c|c|c|c|c|}
\hline No. & Date & M & Place & Remarks \\
\hline 1 & May 22, 1960 & 9.5 & Chile & $\begin{array}{l}\text { 1,900 killed, 3,000 injured, } 2 \text { mil. lost their homes, damage: } \$ 625.5 \\
\text { million, tsunami }\end{array}$ \\
\hline 2 & Mar. 28, 1964 & 9.2 & $\begin{array}{l}\text { Prince William Sound, } \\
\text { Alaska }\end{array}$ & 128 killed, 75 buildings damaged, damage: $\$ 311$ million, tsunami \\
\hline 3 & Dec. 26, 2004 & 9.1 & Sumatra-Andaman Islands & 227,900 killed, damage: $\$ 13$ billion, tsunami \\
\hline 4 & Nov. 4, 1952 & 9.0 & Kamchatka & No one died, damage: $\$ 1$ million, tsunami \\
\hline 5 & Mar. 11, 2011 & 9.0 & $\begin{array}{l}\text { Near the East Coast of } \\
\text { Honshu, Japan }\end{array}$ & $\begin{array}{l}15,703 \text { killed, } 4,647 \text { missing, } 130,927 \text { displaced, the total economic } \\
\text { loss in Japan was } 309 \text { billion US dollars, tsunami }\end{array}$ \\
\hline 6 & Feb. 27, 2010 & 8.8 & Offshore Bio-Bio, Chile & $\begin{array}{l}521 \text { killed, } 56 \text { missing, } 12,000 \text { injured, } 370,000 \text { buildings damaged, } \\
\text { damage: } \$ 30 \text { mill, tsunami }\end{array}$ \\
\hline 7 & Jan. 31, 1906 & 8.8 & Off the Coast of Ecuador & $500-1,500$ killed by tsunami \\
\hline 8 & Feb. 4, 1965 & 8.7 & Rat Islands, Alaska & Damage of $\$ 10,000$, tsunami \\
\hline 9 & Mar. 28, 2005 & 8.6 & $\begin{array}{l}\text { Northern Sumatra, } \\
\text { Indonesia }\end{array}$ & 1,300 killed, damage: 300 buildings damaged, tsunami \\
\hline 10 & Mar. 9, 1957 & 8.6 & Andreanof Islands, Alaska & Damage: $\$ 5$ million, tsunami \\
\hline 11 & Aug. 15,1950 & 8.6 & Assam-Tibet & 1,500 killed, 70 villages are destroyed \\
\hline 12 & Sep. 12, 2007 & 8.5 & $\begin{array}{l}\text { Southern Sumatra, } \\
\text { Indonesia }\end{array}$ & 25 killed, 52,522 buildings damaged, no tsunami \\
\hline 13 & Oct. 13,1963 & 8.5 & Kuril Islands & No data \\
\hline 14 & Feb. 1, 1938 & 8.5 & Banda Sea, Indonesia & Tsunami \\
\hline 15 & Feb. 3, 1923 & 8.5 & Kamchatka & No data \\
\hline 16 & Nov. 11, 1922 & 8.5 & Chile-Argentina Border & Damage $\$ 5-\$ 25$ million, tsunami \\
\hline
\end{tabular}

actuate the problem of seismicity for the world economic system the development of which defines by the countries located in zones of seismic risk. Within the bounds of this problem, the fundamental tasks are detection of the reaction of the global economy on such huge catastrophes, detection of possibilities, boundaries and adaption mechanism of the world economy, counting the risks of seismicity in the global differentiation of labor and production placement of the worldwide corporations, etc..

\section{Seismic Activity}

Earthquakes and tsunami that are similar to the last Japanese earthquake occur on earth quite regular. Table 1 indicates the strongest earthquakes with magnitude higher than 8.5 that have been occurring since 1900. There are evidences that are assuming the intensification of seismologic activity occurring on the second part of 20 century. According to the data of USGS [1], for the last 300 years, seven earthquakes with $M \geq 9$ have occurred and five from them happened during the period between 1952 and 2011 .
Other two events occurred in 1700 and 1868.

Nowadays, seismologists can not predict the place and the time of the next damaging earthquake but there is no doubt that it will occur sometime in the future. Moreover, the question about where the earthquake is going to occur becomes the key point. The exact place is the main factor that determines all the consequences. Most of the strong earthquakes located along oceanic depressions localized in the subduction zones $^{2}$ (Fig. 1). Strongest earthquakes with the $M \geq 9$ occurred in many areas such as Chile, Alaska, Kamchatka and Sumatra. There is no historical data about earthquakes with $\mathrm{M} \geq 9$ along the of subduction zone in area of Japan, where Pacific Plate is moving under Okhotsk Plate [3].

It is important to notice that subduction zones also pass along the most industrially developed regions of

\footnotetext{
${ }^{2}$ Subduction zone is a place where two lithospheric plates come together, one riding over the other. Most volcanoes on land occur parallel to and inland from the boundary between the two plates. Subduction zone is well retraced by seismological profiles until the mantel of the border from the top to the bottom.
} 


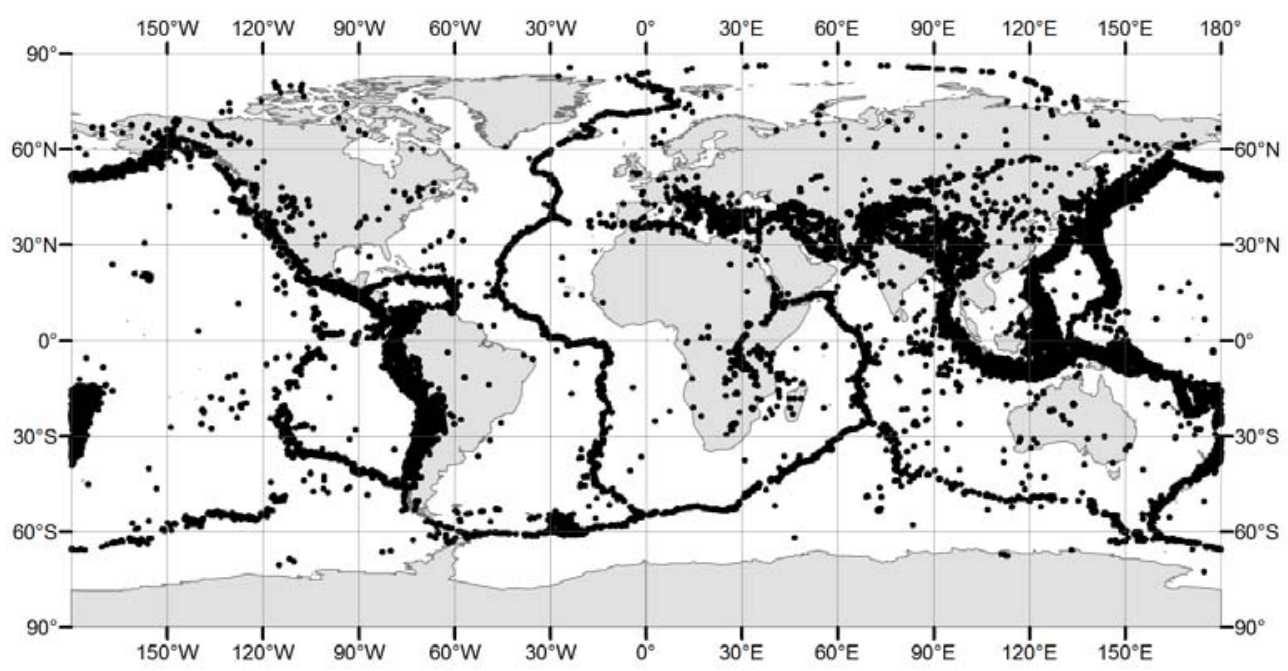

Fig. 1 Earthquakes with the magnitude of greater than 5 occurred for 1973-2010 (according to USGS [4]).

the world (western shores of USA and Canada, eastern shore of Japan) (Fig. 1). Obviously, USA, Canada and Japan are located in the zone of high seismological risk. In fact, the question for these countries is not whether or not the earthquake would occur but when is it going to happen.

Let us consider the influence of Japanese Earthquakes of 2011 on the world economy based on the data of the world exchange and information presented by the Japanese ministry of finance and the ministry of commerce. Primary question that is coming out is about Japanese financial markets - the leading creditor in the world, powerful player and owner of the biggest public debt which in 2011 was $229.6 \%$ of GDP (1st place in the world) [5].

\section{Finance of Japan}

Like in all of developed countries, manufacture of export production to a large extent is defined by the national currency. According to the data of Japanese government in 2011, manufacturing of Japanese exporters kept the profitability with the currency rate of 86.3 Yen/\$US. Correspondingly, the chipper Yen is the greater the profit of Japanese producers, thus the faster the economy of the country will recover. The day before the earthquake the currency was 82.93 Yen/\$US. After Mar. 11, 2011 currency decreased quickly and went down to 78.25 Yen/\$US. After, Yen started to become stronger and on Apr. 6, 2011 currency rate was greater than before the catastrophe - 85.40 Yen/\$US. Later, the government of Japan made dimensioned intervention and increased the quantity of money in the economy (Monetary Base $=$ Banknotes in Circulation + Coins in Circulation + Current Account Balances) by 20.7\% (from 101,003,900 million Yen in February to 112,743,200 million Yen in March and to 121,893,400 million Yen in April 2011 [6].

According to Bloomberg report, Bank of Japan brought to the market approximately $\$ 183$ billion after the earthquake for insuring stability of markets [7]. Consequently, Yen currency relatively to USD became lower than before the March catastrophe: from the beginning of May to the end of July 2011, the currency was fluctuating around 80.5 Yen/USD [8].

\section{Reaction of the World Exchanges}

Let us take a closer look to examine the reaction of the main exchange indexes on the earthquake of Mar. 11, 2011. As an indicator of exchange index, the authors take indexes that are calculated by the company Standard and Poor's [9], which characterize both the regional and global stock markets.

Regional indexes are: S\&P 500 characterize $80 \%$ of 
the US stock market [10]. S\&P Europe 350 - calculated on the basis of the data from 17 main European markets and covers around $70 \%$ of capitalization of European stock market. S\&P Japan 500 - calculated according to data about cost of companies stocks that are presented in Tokyo, Osaka stock exchanges and exchange of JASDAQ. S\&P Asia 50 - exchange index that is counted by the data of four main Asian markets (Hong Kong, Singapore, South Korea and Taiwan) without Japan. As an indicator, which characterizes the global market, was taken index S\&P Global 1200 which is calculated based on data of 31 regional markets and cover around $70 \%$ of the world market capitalization.

Dynamics of indexes characterizing the percentage of change relatively to the corresponding values Jan. 1, 2011 shown in Fig. 2. The data indicates that Earthquake of Mar. 11, 2011 and its consequences affected both regional and global exchange indexes. Decreasing started on the day of Tahoku earthquake. All selected indexes reached its minimal value on Mar. 15, 2011, when the world realized the catastrophe scale. The same day representatives of largest Japanese auto companies made an announcement about stopping the production. Earthquakes and tsunami caused damage to processing systems of the banking industry, thus transactions were closed and it lead to interruption of ATMs, impossibility to transfer money and so on.

Global exchange index (S\&P Global 1200), indexes that characterize markets of USA (S\&P 500) and Europe (S\&P 350) had been rehabilitated by the end of March. Herewith during four days after the catastrophe on Mar. 11, 2011 American index S\&P 500 dropped down by $6.8 \mathrm{pp}$ (percentage points) compare to the value that was on the place one week before the catastrophe and by $1 \mathrm{pp}$ compare to the beginning of 2011. European S\&P 350 decreased by 8 pp compare to the values one week before the catastrophe and by 6.5 compare to the beginning of 2011. As expected the most changeable is S\&P Japan 500. Compare with one week before the catastrophe it dropped by $25.5 \mathrm{pp}$ and at the beginning of the year-15.5 pp. Asian S\&P Asia 50 dropped by 2.8 pp compare to the values that were one week before the catastrophe and by $6.9 \mathrm{pp}$ compare to the beginning of 2011. Asian index tend to decrease before the Earthquake in contrast to European and American indicators. During the first week decrease of Asian index was not as big as indexes that characterize other regions. Japanese (S\&P Japan 500) and Asian (S\&P Asia 50) started to recover but still have not reached the values that they used to have before the catastrophe of Mar. 11, 2011 (Fig. 2).

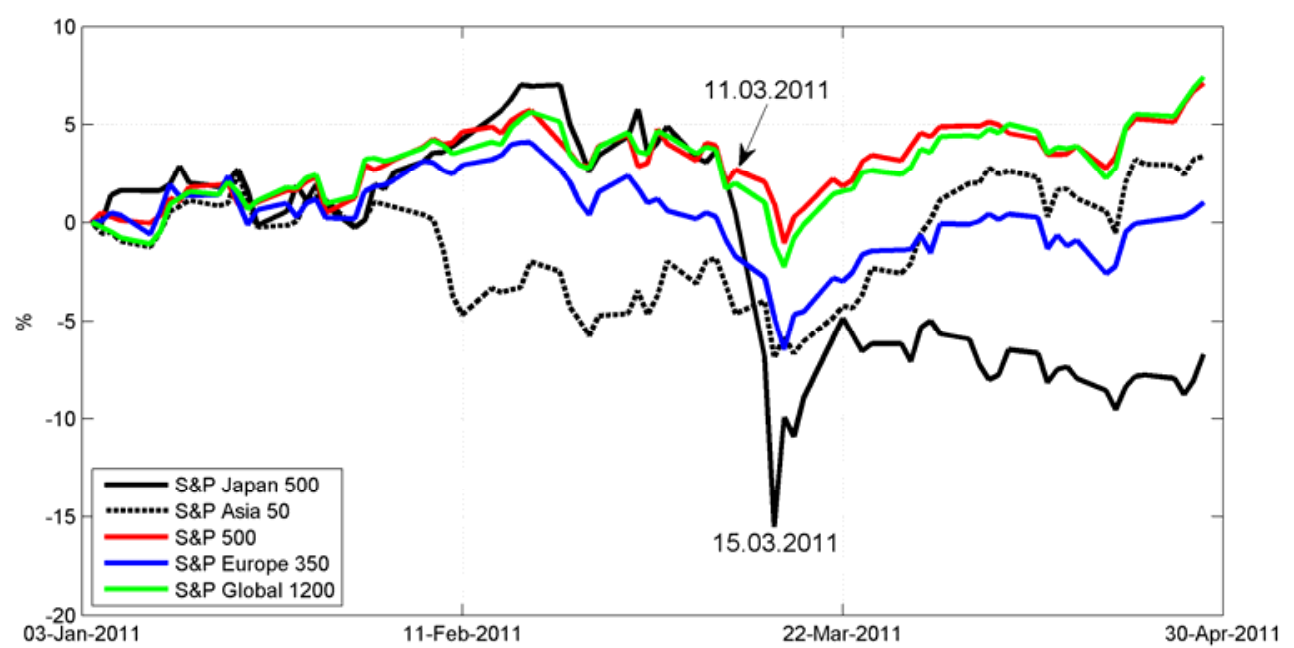

Fig. 2 Dynamics of the exchange indexes reflecting condition of the Japanese stock market (S\&P Japan 500), global stock market (S\&P 1200), European markets (S\&P Europe 350 ), USA (S\&P 500) and Asia (S\&P 50), for the period from January 2011 to April of 2011 (according to Standard \& Poor's [9]). 
Let us consider variations of the global exchange index S\&P Global 1200. Drop compare to one week before the catastrophe was $6.2 \mathrm{pp}$, but compare to the beginning of $2011-2.2 \mathrm{pp}$. In order to conclude, it is important to point out that catastrophe of Mar. 11, 2011 in Japan became the beginning of decreasing of exchange indicators that are characterizing both main regional and worldwide markets. Also, all regional except Japanese and global indexes recover its values by the middle of April 2011 but Japanese index S\&P Japan 500 still has not gone to the level which it used to have before the catastrophe. The difference compare to the beginning of 2011 is between 5 to $8 \mathrm{pp}$. After Mar. 15, 2011 S\&P Japan 500 started to increase till March 22 followed by decrease trend after this date (Fig. 2). Causes of such behavior consist of understanding of real scale of the catastrophe due to the accident on the Fukushima nuclear power plant.

\section{Reaction of the Branch of the World Economy}

Fig. 3 shows the dynamics of Japanese export and import with elimination of seasonal fluctuations during the period from Mar. 2011 to May 2012 [9]. Decreasing of export and import is observed in March, April 2010 compare to February of the same year. In March export of Japan decreased by $7.7 \%$ and import decreased by $1.1 \%$, and in April 2011 by $13.9 \%$ compare to February of the same year. As compared to March and April 2010 decreasing of export was $2.4 \%$ and $12.9 \%$ and import on the opposite side grew by $12.7 \%$ and $11 \%$ (correspond graph in a bigger scale is shown in Fig. 3). To point out, the slump of the export in February-April 2011 were almost 5 times greater than the slump in June-September 2008 (13.9\% against 2.8\%), connected with the global economic crisis. During the crisis year of 2009 the Japanese export drop was $33.2 \%$ compare to 2008 (Fig. 3). Before the Earthquake, export was constantly growing since October 2010 (Fig. 3). Also there were some fluctuations of import in Japan due to the catastrophe: If in March 2011 import decreased by $1.4 \%$ compare to February of the same year, than in April it grew by $4.3 \%$ (Fig. 3). Same or big monthly fluctuations of import occurred even before (March, April 2007, February, March 2010 and so on). The authors suppose that Tahoku earthquake changed the decreasing trend of Japanese import being observed from January 2011.

Thus, the influence of the strongest earthquake on Japanese export in first month after Tahoku earthquake was greater than the influence of the global economic crisis in first two month after its beginning. The available data shows that the impact of Tahoku earthquake on Japanese export is the most dramatic during the first month. Later export started to

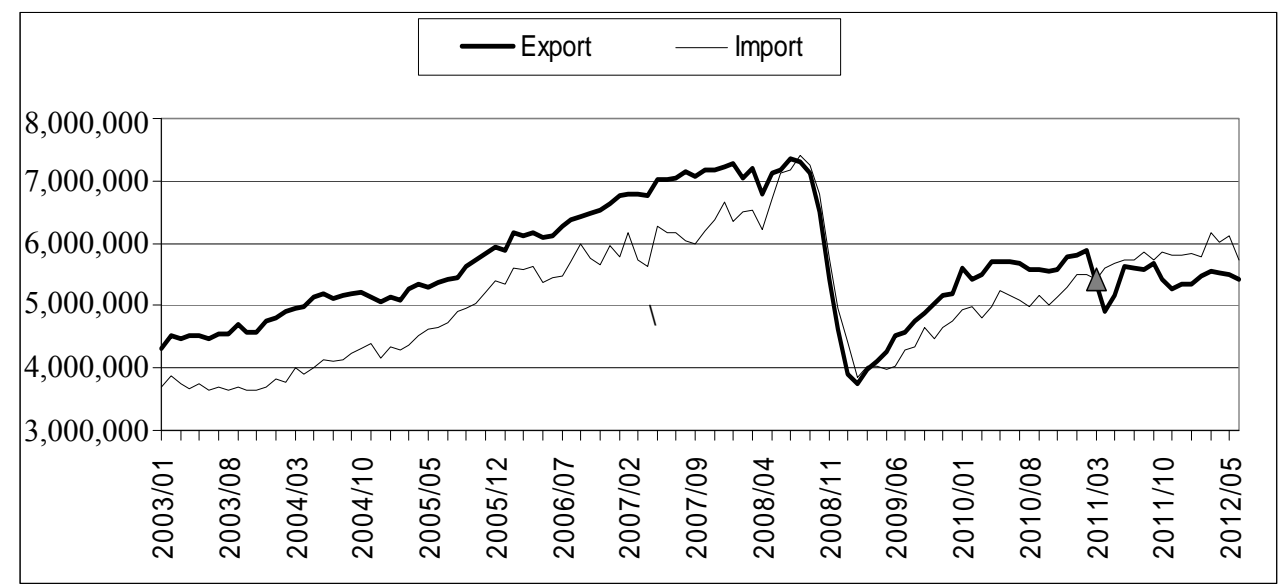

Fig. 3 Seasonally adjusted dynamics of export and import of Japan for the period of Jan. 2003-June 2012 (millions of Yens) [11]. Gray triangle denotes the earthquake of Mar. 11, 2011. 
grow but could not recover its initial values even a year after (Fig. 3). Causes of export drop are obvious-stop of businesses because of earthquake, tsunami and catastrophe on NPP Fukushima.

The main export of Japan consists of chemical, metallurgical industry, machinery constructions and machine-tool constructions [10]. Total percentage of these sectors into overall export is $84 \%$ (Table 2). Most of all production of Hitachi and Mitsubishi corresponds to the structure of Japanese export. These companies produce wide range of products and services: from chemical industry goods to electronics, equipment for hydro-, atomic and power plants, steel, cars, medical equipment, simply everything that makes up the foundation of Japanese export. Similar but not exact analog of the companies in Europe and USA might be Siemens and GE (general electric).

The reaction of these companies on the earthquake of Mar. 11, 2011 is synchronous (Fig. 4). The only difference is on the drop scale. Stocks of Hitachi and Mitsubishi dropped by more than 25 pp stocks of Siemens dropped by 10 pp and stocks of GE dropped by 8 pp. Further behavior of the stocks is different. Siemens's stock prices had recovered by Mar. 30, 2011 and started to demonstrate a little growth, GE had recovered by Apr. 1, 2011.

The cost of Hitachi and Mitsubishi stocks on June 10, 2011 did not achieve the values they used to have before the catastrophe. Hitachi stayed on the level of 7 pp lower than before the crisis and Mitsubishi fixed its position on the $1.3 \mathrm{pp}$ lower and it continued to fall after May 9, 2011. Causes are the consequences of the catastrophe for the production infrastructure and dysfunction of Hitachi and Mitsubishi factories as well as other Japanese machine building businesses and consumers of their goods. Further fix of the stock price on the lower level is possible to explain because the market corrected the prices taking into the account similar risks.

Stocks of other large worldwide cars producers demonstrate quite similar dynamics, for example, Japanese Toyota Motor Corporation, Nissan Motor Co., American General Motors Company, Ford Motor Company and European Volkswagen AG.

Table 2 Japan export structure for 2010.

\begin{tabular}{lc}
\hline Commodity & Share (\%) \\
\hline Foodstuff & 0.6 \\
Raw materials & 1.4 \\
Mineral fuels & 1.6 \\
Chemicals & 10.3 \\
Manufactured goods & 13.0 \\
Machinery & 19.8 \\
Electrical machinery & 18.8 \\
Transport equipment & 22.6 \\
Others (scientific, optical inst, photographic & 11.9 \\
supplies, blank/recorded media) & 100.0 \\
\hline Total &
\end{tabular}

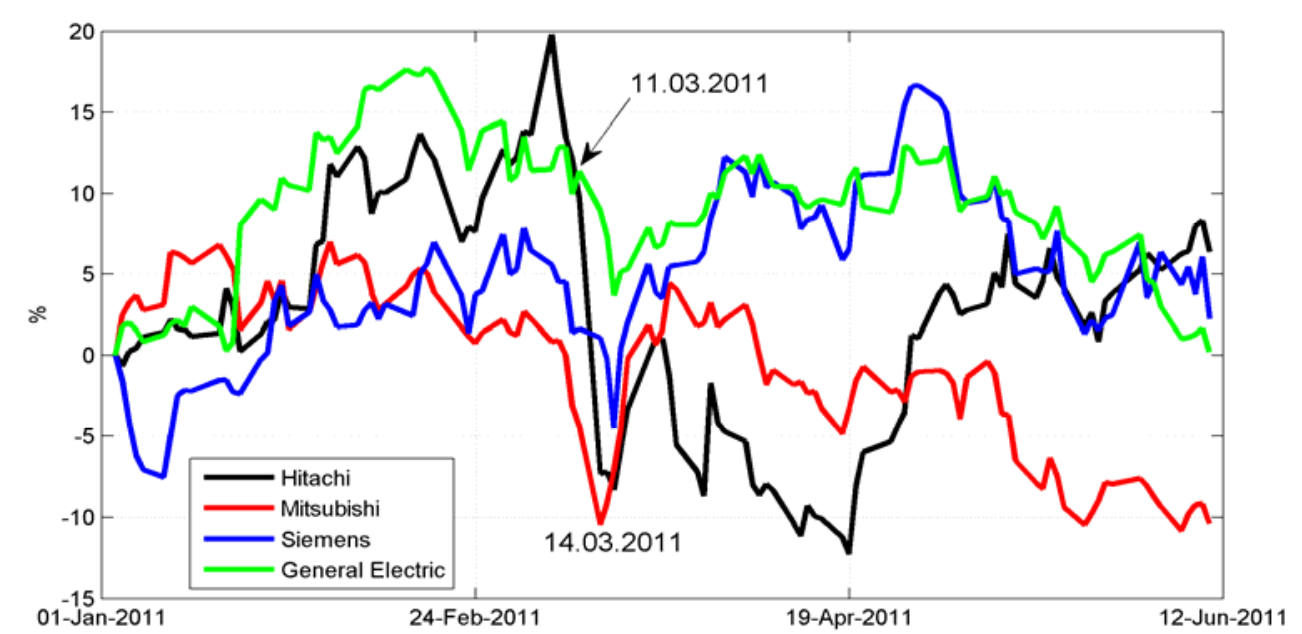

Fig. 4 Dynamics of the stocks prices of the largest companies in Japan (Hitachi, Mitsubishi), Europe (Siemens) and USA (general electric) for the period of Jan. 1, 2011-June 12, 2011 [12]. 


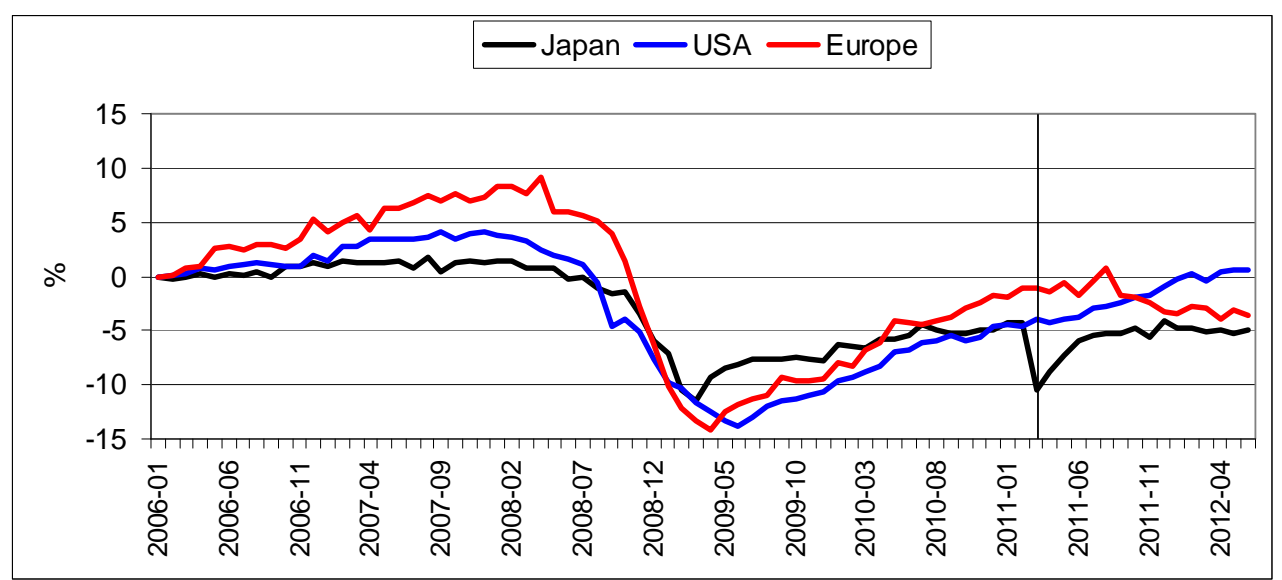

Fig. 5 Dynamics of production characterized by Index of Industry Activity of Japan (by Ministry of Economy) [13], European Industry Production (by EUROSTAT), and Industrial Production Index (INDPRO, by Federal Reserve) from Jan. 2006 to June 2012. Vertical line denotes the time of Tahoku earthquake of Mar. 11, 2011.

Composite index of all industrial activity of Japan except agriculture, forest and fish industry [14] decreased in March 2011 by $6.3 \mathrm{pp}$ (from 97.3 to 90.9 ) compare to February of 2011 (Fig. 5). This is the fastest monthly decrease of industrial production in Japan with account of seasonality at least from 2003. Even during the period of crisis from 2008 to the middle of 2009 monthly decrease in industrial activity of Japan did not exceed 4 pp. In April 2011, Japanese industrial activity started to recover and almost achieved the values it had before the catastrophe by June 2011.

At the same time USA Industrial Production Index (INDPRO) provided by Federal Reserve [15] in Feb.-Mar. of 2011 demonstrated a little growth less than 0.5 pp. (Fig. 5). Although, the Institute for Supply Management (USA) pointed out in its report that some respondents are saying: "The earthquake and related issues in Japan have caused shortages of some automotive equipment, negatively impacting global automotive production" [16].

Like the US case, Tahoku Earthquake of Mar. 11, 2011 did not have noticeable influence on Euro zone production. This can be seen from the dynamics of European Industry Production provided by EUROSTAT [17] (Fig. 5).

Thus, Tahoku earthquake and followed tsunami significantly impacted Japanese industry but not the ones of Europe and USA.

\section{Conclusions}

To conclude, unique in its scale catastrophe substantially affected the world markets and in short run in some indicators, it exceeds the effect of the world financial crisis. Also, negative expectations and panic moods of worldwide stocks about the consequences from the catastrophe in the first week after it happen exceeded the reality. Mostly, it was like that because considerable production facilities of Japanese corporations are located outside of Japan. Also, considerable drop of worldwide exchange indicators of largest companies in USA and Europe connect to the substantial dependence on the production that Japan manufacture.

Distribution of strong $(M \geq 9)$ earthquakes in time indicates that from the second part of 20 century the activation of seismologic activity on earth is occurring. This fact, also spatial distribution of earthquakes and economic consequences of the catastrophe in Japan emphasized the relevance of taking into the account the seismological risks when placing plants.

Increase of seismic activity on Earth that is observing from the second part of 20 century has led to the inevitability of qualified revision of perceptions of earthquakes with the view to economics as well as pointed events which have an influence on overall 
world situation or not so essentially, or its consequences will smooth over. Strongest earthquake of Mar. 11, 2011 near Japan and its consequences prove this thesis. Thus, it is necessary to treat possible strong earthquakes in different regions of the world as one very important factor that can affect the world economy. It is necessary to treat possible strong earthquakes in different regions of the world to be a very important factor that can affect the world economy.

\section{Acknowledgments}

This research was supported by Russian Foundation of Basic Research (project Nu 13-05-00158) Russian Ministry of Science and Education (project $\mathrm{Nu}$ 2012-1.2.1-12-000-3002-007).

\section{References}

[1] United States Geological Survey, Information of Historical Earthquakes, http://earthquake.usgs.gov/ earthquakes/world/historical_mag.php (accessed Jan. 1, 2013).

[2] B. Geoff, Researchers Call for Nuclear Data Release, http://www.nature.com/news/2011/110613/full/news.201 1.366.html (accessed Jan. 1, 2013).

[3] S. Ozawa, T. Nishimura, H. Suito, T. Kobayashi, M. Tobita, T. Imakiire, Coseismic and postseismic slip of the 2011 magnitude-9 Tohoku-Oki earthquake, Nature 475 (2011) 373-376.

[4] United States Geological Survey, Global Earthquake Catalog, http://earthquake.usgs.gov/earthquakes/ eqarchives/epic/ (accessed Jan. 1, 2013).

[5] Global Finance, Public Debt as a Percentage of GDP in Countries around the World, http://www.gfmag.com /component/content/article/119-economic-data/12370-pu blic-debt-percentage-gdp.html\#axzz2jqG6QLRq (accessed Nov. 6, 2013).
[6] Bank of Japan, Main Time-series Statistics (Monthly), http://www.stat-search.boj.or.jp/ssi/mtshtml/m_en.html (accessed Jan. 1, 2013).

[7] Bloomberg, Japan Adds \$183 Billion to Stabilize Markets After Quake, http://www.bloomberg.com/news/ 2011-03-13/japan-readies-massive-liquidity-as-boj-gauge s-risk-to-post-quake-economy.html (accessed Jan. 1, 2013).

[8] Google Finance, US Dollar (\$)/Japanese Yen (¥), http://www.google.com//finance?chdnp=1\&chdd=1\&chd $\mathrm{s}=1 \& \mathrm{chdv}=1 \& \mathrm{chvs}=$ Linear $\&$ chdeh $=0 \&$ chfdeh $=0 \&$ chdet $=1309517547283 \& \mathrm{chddm}=178149 \& \mathrm{q}=$ CURRENCY:US DJPY\&ntsp=0 (accessed Jan. 1, 2013).

[9] Standard \& Poor's, Indexes, http://www.spindices.com/ (accessed Nov. 6, 2013).

[10] Standard \& Poor's, S\&P 500 Index, http://www.spindices.com/indices/equity/sp-500 (accessed Jan. 1, 2013).

[11] Ministry of Finance, Trade Statistics of Japan, http://www.customs.go.jp/toukei/shinbun/trade-st_e/sadj_ e.htm (accessed Jan. 1, 2013).

[12] Stock Data, http://wikiposit.org/w (accessed Jan. 1, 2013).

[13] Ministry of Economy, Indices of All Industry Activity, http://www.meti.go.jp/english/statistics/tyo/zenkatu/index .html (accessed Jan. 1, 2013).

[14] Ministry of Finance of Japan, Trade Statistics, Values of Exports and Imports, 2010 , http://www.customs.go.jp/toukei/shinbun/trade-st_e/2011 /2011_117e.pdf(accessed Mar. 14, 2011).

[15] Federal Reserve, USA Industrial Production Index (INDPRO), http://research.stlouisfed.org/fred2/ $\operatorname{graph} /$ ?s[1][id]=INDPRO) (accessed Jan. 1, 2013).

[16] Institute for Supply Management, Manufacturing ISM Report on Business, July 1, 2011, http://www.ism.ws/news/NewsReleaseDetail.cfm?ItemN umber $=21768$ (accessed Nov. 6, 2013).

[17] Eurostat, European Industry Production, http://epp.eurostat.ec.europa.eu/portal/page/portal/short_t erm_business_statistics/data/database) (accessed Jan. 1, 2013). 